\title{
Correction to: Wharton Marketing: Where Academia Meets Practice
}

Eric T. Bradlow ${ }^{1} \cdot$ Raghuram lyengar $^{1} \cdot$ Barbara E. Kahn ${ }^{1} \cdot$ Catherine (Cait) Lamberton ${ }^{1} \cdot$ Leonard M. Lodish $^{1}$. Robert J. Meyer ${ }^{1} \cdot$ Yoram (Jerry) Wind ${ }^{1}$

Published online: 13 November 2021

(C) Springer Science+Business Media, LLC, part of Springer Nature 2021

\section{Correction to: Customer Needs and Solutions}

https://doi.org/10.1007/s40547-021-00121-0

The original article unfortunately was published with errors.

Two very important scholars were left out in the article.

The original article has been corrected.

Publisher's Note Springer Nature remains neutral with regard to jurisdictional claims in published maps and institutional affiliations.

The original article can be found online at https://doi.org/10.1007/ s40547-021-00121-0.

Eric T. Bradlow

ebradlow@wharton.upenn.edu

1 University of Pennsylvania Wharton School, Philadelphia, USA 